\title{
Highlights on mental processes in management
}

\author{
Vladimir Modrak ${ }^{1}$, Mirela Teodorescu², Daniela Gîfu ${ }^{3, *}$ \\ ${ }^{1}$ Technical University of Košice, Bayerova 1, 08001, Prešov, Slovakia \\ 2University of Craiova, A. I. Cuza 13, 200585, Craiova, Romania \\ 3"Alexandru Ioan Cuza" University of laşi, Bd. Carol I no. 11, 700506, Iaşi, Romania \\ *E-mail address: danigifu@yahoo.com
}

\begin{abstract}
Mental process or cognition process is a term often used for all the acts that people can do with their minds. These acts include perception, introspection, reasoning, creativity, imagination, memory, idea, belief, volition, and emotion. A mental event represents an instance involved in cognitive process. The perceiving of the event is different from each event depending of perceiving capacity of that instance. Along human existence, philosophers such as Aristotle, Plato, Descartes, Leibniz, Spinoza, Kant, Heidegger, Wittgenstein, Daniel Dennett and et alli. The structure of the mental process is part of psychology and psychologists such as Sigmund Freud and William James who developed essential theories about the nature of the human mind. In the last decades of the 20th and early 21 st centuries the domain of cognitive science emerged and developed many varied approaches related to the description of mind and its related phenomena. The field of artificial intelligence is the possibility of non-human minds also explored, and works closely in relation with cybernetics and information theory to understand the ways in which human mental phenomena can be replicated by non-biological machines. The mental process domain is by far vast, this study is suggesting only to highlight some of aspects, subjects of thought for human being.
\end{abstract}

Keywords: mind; cognition; emotional intelligence; memory map; self-esteem; management

\section{BASICS OF COGNITION}

By cognition process, the sensory input is transformed, reduced, elaborated, stored, recovered, and used to get different events (Neisser, 1967). In science, acts such as attention of working memory, comprehending and producing language, calculating, reasoning, problem solving, and decision making are performed by cognition (Borowski, 2014; Powell, 2014). Mental process is studied by disciplines as psychology, philosophy and linguistics, each of them customizing terms of research, for example, in psychology and cognitive science, "cognition" usually refers to an information processing view of an individual's psychological functions, "social cognition to explain attitudes, attribution, and group dynamics" (Sternberg \& Sternberg, 2009).

In cognitive psychology and cognitive engineering, cognition is assumed to be “information processing in a participant's or operator's mind or brain" (Blomberg, 2011).

The word "Cognition" dates back to the 15th century when it meant "thinking and awareness" (Revlin, 2012). The study of the cognitive process came about more than twenty- 
three centuries ago, beginning with Aristotle and his interest of the internal processes of the mind and how they affect the human experience and existance (Durant, 2006). The cognitive areas pertaining to memory, perception, and mental imagery were explored by Aristotle (Vlăduţescu, 2013; Vlăduţescu, 2014).

Aristotle emphasises the memory reference to past, i.e. "primary perceptual analyser", that is sensus communis. Memory is impossible without an image (Bloch, 2007). A memory is a mental image ("phantasm") in which Aristotle defines in De Anima, as an appearance which is imprinted on the part of the body that forms a memory. Aristotle's studies were based on empirical evidence; scientific information that is gathered through thorough observation and conscientious experimentation (Matlin, 2009). Later, psychologists as Wilhelm Wundt, Herman Ebbinghaus, Mary Whiton Calkins, and William James, would research and bring their contributions to the study of cognition.

\section{KANT'S BASIC THEORY OF COGNITION}

Kant assumes that human cognition involves the especial ability to "think the particular as contained under the universal" (Kant, 1965). It can be asserted that "think of particular individual things as belonging to general kinds: this is a bird, that a tree. We form concepts into systematic hierarchies: grizzlies and polar bears are kinds of bear; bears and dogs are kinds of mammal; and so on. Similarly we can consider an abstract feature, such as 'redness', which we have encountered in many different individual experiences, and apply it to other objects: this apple is red, that balloon is red" (Palmer, 2008). These are examples of judgment: the mental act of applying general concepts to particulars, in Kant's terminology. To perform this act, Kant, involves the coordination of two mental abilities, "understanding" and "imagination" respectively, defined in Critique of Pure Reason. In Critique of Judgment, Kant argues that an internal signal (of pleasure) accompanies the coordination of imagination and understanding in judging as a new development to his theory (Palmer, 2008).

In his view of cognition, Kant opposes the empiricist conception that all mental contents are performed from experience. The notion of "a priori conditions" of cognition was brightly introduced by Kant in the Critique of Pure Reason. Kant highlighted that certain aspects of our knowledge of the world are not based on but are put in our experience of the world by the mind, in our mental representations of an objective world (Kant, 1965). They are identified two basic kinds of conditions: "a priori pure forms" of space and of time, and "a priori pure concepts"; the analytic of concepts, schematically illustrated by a table of the categories, providin $g$ a catalogue of twelve pure (a priori) concepts of the understanding. divided into four groups: (I) of quantity (unity, plurality, totality), (II) of quality (reality, negation, limitation), (III) of relation (of inherence and subsistence, of causality and dependence, of community), and (IV) of modality (possibility or impossibility, existence or nonexistence, necessity or contingency) (Kant, 1990, p. 62)

Knowledge may be performed by the combined operation of the sensibility and the understanding. The intuitions are produced by sensibility that may be the source of empirical concepts. Also the imagination may provide representations of objects if these objects are not present for intuition. The understanding is an act of the synthesis of intuitions and concepts. Understanding may unite multiplicity of intuitions and representations. The synthetic unity of intuitions and representations is necessary a priori for the understanding. The understanding produces a unity that cannot be attained only by the faculty of intuition. Apperception is an act of self-consciousness that may accompany any act of representation, may unite the manifold 
content of intuitions, may connect many intuitions and representations within a single consciousness, may be pure (a priori) or empirical (a posteriori). Apperception may have an analytic or synthetic unity, may have an originally synthetic unity, and thus its synthetic unity may be a condition for its analytic unity, it may also have a subjective (empirical) unity and an objective (transcendental) unity. Every cognition process consists of two elements: (1) an intuition, and (2) a concept. A concept is given its object by an intuition. Every concept of an object is based on a corresponding intuition of that object. A concept without object is a thought, but it is not an element of cognition. Cognition is made possible by the combined operation of intuition and conceptual thought. According to Kant, all intuitions are sensory. Space and time are pure intuitions that are non-empirical, because they do not correspond to objects of experience. Space and time are thus a priori intuitions they establish conditions for possible experience (Smarandache \& Vlăduţescu, 2014).

Faculties of cognition consist of intuition, understanding, judgment, and reason (Kant, 1990, p. 97). Intuition is classified as a lower faculty of cognition, while understanding, judgment, and reason may be classified as higher faculties of cognition. Intuition is the faculty of receiving impressions. Understanding is the faculty of producing rules or concepts. Judgment is the faculty of determining whether a rule or concept is subsumed under other rules or concepts. Reason is the faculty that produces principles, and it is considered the highest faculty of cognition (Gîfu \& Teodorescu, 2014; Dima \& Vlăduţescu, 2012).

Each of the categories in the table of principles represents a principle of the application of the pure understanding. The principle of axioms of intuition is that all intuitions have a quantity (or degree) of extensity. The principle of anticipations of perception is that the reality of phenomena has a quantity (or degree) of intensity. The principle of analogies of experience is that experience is a synthetic unity of perceptions. The principle of the postulates of empirical thought is that there are formal, material, and universal conditions of experience. All a priori cognitions are given their objective reality by their possibility of experience. All a posteriori cognitions are given their objective reality by objects of experience.

\section{INTERIOR DIALOG}

The Dutch psychologist Hubert Herman initiated and developed the Dialogical Self Theory (DST) including two concepts, self and dialogue, both of them in such a way that a more profound understanding of the interconnection of self and society is achieved. The concept of self refers to something "internal", something that takes place within the mind of the individual person (Rosenberg, 1979), while dialogue is specifically associated with something "external", that is, processes that take place between people involved in communication.

Dialogical Self as a central concept it is inspired by William James and Mikhail Bakhtin. They worked in different countries and, first in USA, the later in Rusia, in different disciplines, psycology and literary sciences, in different theoretical traditions pragmatism and dialogism.

William James (1890) provided a prosperous basis for psychology of the self. As a distinction between the $I$ and the $M e$, which, according to Morris Rosenberg (Rosenberg, 1979), is a classic distinction in the psychology of the self. According to James's view the "I is equated with the self-as-knower and has three features: continuity, distinctness, and volition" (Damon $\&$ Hart, 1982). The continuity of the self-as-knower is expressed in a sense of personal identity, a feeling of distinctness from others, or individuality, is also characteristic of the self-asknower, "a sense of personal volition is reflected in the continuous appropriation and rejection 
of thoughts by which the self-as-knower manifests itself as an active processor of experience" (Hermans, 2001).

In William James's quotation of characters (self-positions) which he sees as belonging to the Me/mine, such characters are more explicitly elaborated in Mikhail Bakhtin's (Bakhtin, 1973) "metaphor of the polyphonic novel", which became a source of inspiration for later dialogical approaches to the self. According to this instance, he draws on the idea that in Dostoyevsky's works there is not a single author at work - Dostoyevsky himself - but several authors or thinkers, portrayed as characters such as Ivan Karamazov, Myshkin, Raskolnikov, Stavrogin, and the Grand Inquisitor.

These characters are not presented as obedient slaves in the service of one author-thinker, Dostoyevsky, but treated as independent thinkers, each of them with their own view of the world. Each hero is put forward as the author of his own ideology, and not as the object of Dostoyevsky's finalizing artistic vision. Rather than a "multiplicity of characters within a unified world, there is a plurality of consciousnesses located in different worlds" (Hermans, 2001b). Similarly to a polyphonic musical composition, multiple voices accompany and oppose one another in dialogical ways. In bringing together different characters in a polyphonic construction, "Dostoyevsky creates a multiplicity of perspectives, portraying characters conversing with the Devil (Ivan and the Devil), with their alter egos (Ivan and Smerdyakov), and even with caricatures of themselves" (Raskolnikov and Svidrigailov) (Bakhtin, M. (1973).

The brain everytime has the tendency to "voice out" thoughts in a specific language that's native to you. But the efficient and normal mode of operation in a brain is when it operates in "silence", without coding or decoding every thought into wordful noise, operation taking of brain resources (Marr, 2010). The constant translation of thoughts leads to a noisy brain activity, which is a huge source of irritation and discomfort, disturbing from other activities.

In the unconscious state of being, the process of translating of the thoughts happening in the brain, is causing an inefficient and sluggish mental process, discomfort of a noisy mind. In the state of consciousness, you can "disable" the translation process and allow the mind to operate in silence, you can coordinate it. The translation of thoughts into "language" is just the feature available only in the human brain, it is depending on the receipted signals, and it's not required to be activated all the time.

\section{EMOTIONAL INTELLIGENCE}

Refering to emotions we have to appeal Plato's statement "All learning has an emotional base". Emotional intelligence (EI) is the ability to monitor one's own and other people's emotions, to understand, interpret, and respond to discriminate between different emotions and label them appropriately, and to use emotional information to guide thinking and behavior (Coleman, (2008). There are three models of EI:

1. ability model, focuses on the individual's ability to process emotional information and to navigate through the social environment, developed by Peter Salovey and John Mayer, (Salovey, Peter; Mayer, John; Caruso,2004);

2. trait model, comprehend behavioral dispositions and self perceived abilities, it is measured through self report, developed by Konstantin Vasily Petrides, (Petrides, Furnham, 2001); 
3. mixed model, a combination of both ability and trait of emotional intelligence. It defines EI as an array of skills and characteristics that drive leadership performance, as proposed by Daniel Goleman (Goleman,1998).

The model introduced by Daniel Goleman (Goleman, 1998) focuses on EI as a wide array of competencies and skills that drive leadership performance. This model outlines five main EI constructs: self-awareness, self-regulation, social skill, empathy, motivation. Each construct of emotional intelligence includes a set of competencies. Emotional competencies are not innate talents, they are learned capabilities that must be worked on and can be developed to achieve outstanding performance.

\section{SELF ESTEEM}

Self-esteem phrase represents our beliefs about ourselves - what we think about the type of person we are, our abilities, the positive and negative things about us and what we expect for our future. If the self-esteem is healthy, the beliefs about ourselves will generally be positive. Everybody may experience difficult times in his life, but import is to be able to deal with these without them having too much of a long-term negative impact on our mind. If the self-esteem is low, the beliefs about ourselves will often be negative.

The mental will tend to focus on weaknesses or mistakes that everybody have made, and may find it hard to recognize the positive parts of the individual personality. It also appears the status of blaming yourself for any difficulties or failures that you have. Self-esteem is an evaluation of ourselves; it is the feedback of how we perceive our value to the world and how valuable we think we are for the others. Self-esteem affects our trust in others, our relationships, our work - almost every part of our lives. Positive self-esteem supplies the strength and flexibility to take charge of our lives and grow from our mistakes without the fear of rejection.

Some outward signs of positive self-esteem: confidence, optimism, self-direction, nonblaming behavior, awareness of personal strengths, ability to make mistakes and learn from them, ability to accept mistakes from others, ability to solve problems, independent and cooperative attitude, feeling comfortable with a wide range of emotions, ability to trust others, a good sense of personal limitations, the ability to say no. Low self-esteem is an exhausting condition that keeps away individuals from realizing their full potential. A person with low self-esteem feels unworthy, pesimist, incapable, and incompetent. Some signs of low selfesteem: negative view of life, perfectionist attitude, blaming behavior, fear of taking risks, feelings of being unloved and unlovable.

Maslow portrayed a hierarchy of needs in the shape of a pyramid with the largest, most fundamental levels of needs at the bottom and the need for self-actualization at the top (Maslow, 1954,;Mittelman, 1991). The most fundamental and basic four layers of the pyramid contain "deficiency needs" or "d-needs" as Maslow called: esteem, friendship and love, security, and physical needs. If these "deficiency needs" are not met - with the exception of the most fundamental (physiological) need - there may not be a physical indication, but the individual will feel anxious and tense. The most basic level of needs, as Maslow's theory suggests, must be met before the individual will strongly desire (or focus motivation upon) the secondary or higher level needs. Maslow also invented the term "metamotivation" to describe the motivation of people who go beyond the scope of the basic needs and strive for constant improvement (Kremer, Kremer; Hammond, 2013). The human mind and brain are complex and they have parallel processes running at the same time, thus can occur at the same time, many different motivations from various levels of Maslow's hierarchy (Maslow, 1954). 
Albert Ellis in introduction of his the book "The Myth of Self-Esteem" starts by asking: "Is self-esteem a sickness?" Then, he states that "self-esteem is probably the greatest emotional disturbance known to the human race, if we understand self-esteem in the way in which it is usually defined" (Ellis, 2005). When talking about conditional self-esteem, Ellis refers to Nathaniel Branden who became a guru of self-esteem (Branden,1969). Branden stated that selfesteem is always a positive concept and it is not possible to have too much self-esteem.

He divided the concept of self-esteem into two different evaluations: how well can person to deal with challenges in his/her life (self-efficacy) and how one sees his/her own worth as a person (self-worth). At the time, Branden's view on self esteem was more related to achievements and a constant push for excellence. From Branden's point of view, we could say that self-esteem is something to be earned (Branden,1969). But, along the years, Branden's personal views have changed in a softer direction and he has talked also about pseudo selfesteem, which relies mainly to external sources than to a person's internal views (Branden,1969; Green, 2003; Ellis, 2005; Grabara, Kolcun \& Kot, 2014).

\section{LAW OF ATTRACTION}

By focusing on positive or negative thoughts, one can bring positive or negative results, meaning the law of attraction, the name given to the belief according to the principle "like attracts like" (Redden, Mathur, 2013; Wayne, 2005). This belief is based upon the idea that people and their thoughts are both made from "pure energy", and the belief that like energy attracts like energy (Zamfir \& Vlăduţescu, 2003; Vlăduţescu, 2008; Wayne, 2005). One example used by a proponent of the law of attraction is that if a person opened an envelope expecting to see a bill, and concentrate his mind on that purpose, then the law of attraction would "confirm" those thoughts and contain a bill when opened. A person who decided to instead expect a cheque might, under the same law, find a cheque instead of a bill (Carmichael, Radford, 2012). Although there are certain cases where positive or negative attitudes can produce corresponding results (principally the placebo and nocebo effects), there is no scientific basis to the law of attraction (Carroll, Todd, 2013).

\section{CONCLUSIONS}

Before to develop languages, the brain naturally operated in silence, and hence it was highly efficient and caused very little tiredness in the being. Language provides a huge advantage in allowing us to communicate thoughts with each other, but it's completely unnecessary to keep talking to ourselves (as if we were talking to another person). You don't have to talk to yourself in a language; you can understand your thoughts without requiring language (Marr, 2010). Remember that "language" was devised, or invented, by humans, whereas "thoughts" are inherent to your being. We don't have to use a "language" to know our thoughts, we can know our thoughts in silence itself - thought in its pure nature (energy) is always silent. It's the translation of thoughts that makes it noisy. Some translated thoughts can get stuck in the memory due to over-repetition, emitting scenarios, lists (owing to your unconscious attention to it), and can become a source of irritation and discomfort - the solution is to be more stable in our awareness so that we are not fueling the repetition any further, and thus allowing its dissolution. We have to remember also, Socrates assertion, "The only true wisdom is in knowing you know nothing". 


\section{ACKNOWLEDGMENT}

This work was partially supported by the grant number $33 \mathrm{C} / 2014$, awarded in the internal grant competition of the University of Craiova.

\section{References}

[1] U. Neisser (1967). Cognitive psychology. Englewood Cliffs: Prentice-Hall.

[2] Andrzej Borowski, International Letters of Social and Humanistic Sciences 14 (2014) 7-17.

[3] Jason L. Powell, International Letters of Social and Humanistic Sciences 16(2) (2014) 177-183.

[4] Ştefan Vlăduţescu, European Scientific Journal 9(32) (2013).

[5] M. Bakhtin (1973). Problems of Dostoevsky's poetics (2nd edn.; R. W. Rotsel, Trans.). Ann Arbor, MI: Ardis.

[6] Nathaniel Branden, (1969). The Psychology of Self-Esteem: A New Concept of Man's Psychological Nature. Nash Publishing Corporation

[7] O. Blomberg, International Journal of Aviation Psychology 21(1) (2011) 85-104.

[8] Andrzej Borowski, International Letters of Social and Humanistic Sciences 14 (2014) $33-41$.

[9] Ştefan Vlăduțescu (2008). Mesaje şi texte gânditoare. Craiova: Editura Sitech.

[10] Marian Siminică, Aurelia Traistaru, International Journal of Education and Research 1(12) 2013.

[11] A. Traistaru, M. Avram, International Letters of Social and Humanistic Sciences 13 (2014) 79-88.

[12] Florentin Smarandache, Ştefan Vlăduţescu (2014). Communication Neutrosophic Routes. Columbus, OH: Educational Publishing.

[13] Robert Todd Carroll (19 December 2013). Law of attraction. The Skeptic's Dictionary. Retrieved 17 April 2014.

[14] Andrew Coleman (2008). A Dictionary of Psychology. (3 ed.). Oxford University Press.

[15] Andrzej Borowski, International Letters of Social and Humanistic Sciences 4 (2013) 70-74.

[16] Ștefan Vlăduțescu (2004). Studii de Psihologie generală şi Psihologie socială. Craiova: Editura Sitech.

[17] W. Damon, D. Hart, Child Development (1982) 841-864.

[18] Will Durant (2006). The Story of Philosophy. Simon \& Schuster, Inc.

[19] Ioan Constantin Dima, Ştefan Vlăduţescu (2012). Persuasion elements used in logistical negotiation: Persuasive logistical negotiation. Saarbrucken: LAP Lambert Academic Publishing.

[20] Alina Tenescu, Mirela Teodorescu, Communications in Applied Sciences 2(1) (2014). 
[21] Ştefan Vlăduţescu (2013). What Kind of Communication Is Philosophy. Jokull.

[22] Albert Ellis (2005). The Myth of Self-Esteem. New York: Prometheus books.

[23] D. Goleman (1998). Working with emotional intelligence. New York: Bantam Books

[24] H. J. Hermans, Culture \& Psychology 7(3) (2001) 243-281.

[25] Daniela Gîfu, Mirela Teodorescu, International Letters of Social and Humanistic Sciences 17 (2014) 119-127.

[26] Andrezj Borowski, International Letters of Social and Humanistic Sciences 2 (2014) 110-121.

[27] Florentin Smarandache, Ştefan Vlăduţescu (2014). Neutrosophic Emergences and Incidences. Saarbrucken: LAP Lambert Academic Publishing.

[28] Ioan Constantin Dima, Mirela Teodorescu, Daniela Gifu, International Letters of Social and Humanistic Sciences 20 (2014) 46-55

[29] James, W. (1890). The principles of psychology (Vol. 1). London: Macmillan.

[30] Andrezj Borowski, International Letters of Social and Humanistic Sciences 3 (2013) 69-74.

[31] Kant, I. (1990). Critique of pure reason.New York: St. Martin's Press.

[32] Ş. Vlăduțescu, E. M. Ciupercă (2013). Next Flood Level of Communication: Social Networks. Aachen: Shaker Verlag.

[33] Daniela Gîfu, Mirela Teodorescu, International Letters of Social and Humanistic Sciences 18 (2014) 34-38.

[34] A. Borowski, International Letters of Social and Humanistic Sciences 11 (2014) 1-168.

[35] William Kremer Kremer, Claudia Hammond (2013). Abraham Maslow and the pyramid that beguiled business. Derdan

[36] David Marr (2010). Vision. A Computational Investigation into the Human Representation and Processing of Visual Information. New York: Henry Holt.

[37] Vinita, Mathur (2013). Power of Mankind - Visualization. humanenrich.com. Retrieved

[38] Ștefan Vlăduțescu (2013). Principle of the Irrepressible Emergence of the Message. Jokull.

[39] Tomáš Hes, Anna Poledňáková, International Letters of Social and Humanistic Sciences 2 (2013) 18-31.

[40] Mohsen Mehrara, Masoumeh zirak, International Letters of Social and Humanistic Sciences 2 (2013) 32-38.

[41] Andrzej Borowski, International Letters of Social and Humanistic Sciences 3 (2013) 46-53.

[42] Donovan A. McFarlane, International Letters of Social and Humanistic Sciences 4 (2013) 35-44.

[43] Kinga Dziwańska, International Letters of Social and Humanistic Sciences 7 (2013) 96-112. 
[44] Mohsen Mehrara, Maysam Musai, International Letters of Social and Humanistic Sciences 8 (2013) 1-7.

[45] Margaret Matlin (2009). Cognition. Hoboken, NJ: John Wiley \& Sons, Inc.

[46] W. Mittelman, Journal of Humanistic Psychology 31(1) (1991) 114-135.

[47] A. Maslow (1954). Motivation and personality. New York, NY: Harper.

[48] Ștefan Vlăduțescu, International Letters of Social and Humanistic Sciences 10 (2014) 100-106.

[49] M. Rosenberg (1979). Conceiving the self. New York: Basic Books.

[50] Konstantin Petrides, Adrian Furnham, European Journal of Personality (2001) 425-448

[51] Linda Palmer (2008), Kant and the brain: A new empirical hypothesis, Department of Philosophy, Carnegie Mellon University.

[52] Ștefan Vlăduțescu, International Letters of Social and Humanistic Sciences 7 (2014) 8-13.

[53] Colhon M. (2013). Automatic Lexical Alignment between Syntactically Weak Related Languages. Application for English and Romanian. In Computational Collective Intelligence. Technologies and Applications (pp. 266-275). Springer Berlin Heidelberg.

[54] Janusz Grabara, Michal Kolcun, Sebastian Kot, International Journal of Education and Research 2(2) (2014).

[55] Mădălina Giorgiana Mangra, Elena Antoanela Cotoc, Aurelia Traistaru, A., Journal of Studies in Social Sciences 6(1) (2013).

[56] Dumitru Zamfir, Ştefan Vlăduţescu (2003). Percepţia şi audiopercepţia, o abordare cognitiv-constructiv-operaţioanală. Bucureşti: Editura Didactică şi Pedagogică.

[57] Sebastian Kot, Janusz Grabara, Michal. Kolcun, International Letters of Social and Humanistic Sciences 15 (2014) 1-6.

[58] Peter Salovey, John Mayer, David Caruso, Psychological Inquiry (2004) 197-215.

[59] R. J. Sternberg, K. Sternberg (2009). Cognitive psychology (6th Ed.). Belmont, CA: Wadsworth, Cengage Learning.

[60] Ștefan Vlăduțescu, Journal of Sustainable Development Studies 6(1) (2014).

[61] Sebastian Kot, Beata Ślusarczyk, Applied Mechanics and Materials 309 (2013) 206-212.

[62] J. H. Gasderell, International Letters of Social and Humanistic Science 22 (2014) $85-91$.

[63] Stefan Vladutescu, Analele Universităţii din Craiova. Seria Ştiinţe Filologice. Lingvistică (1-2) (2013) 355-363.

[64] Max G. Craig, Journal of Studies in Social Sciences 8(1) (2014).

[65] Jason L. Powell, International Letters of Social and Humanistic Sciences 7 (2014) 22-30.

[66] Agnieszka Ulfik, Stefan Nowak, Polish Journal of Environmental Studies 23(3) (2014). 
[67] Vlad Roşca, Theoretical and Applied Economics, 1(1) (2012) 127.

[68] Sebastian Kot, Beata Ślusarczyk, The Journal of American Business Review Cambridge (2014).

[69] Jason L. Powell, International Letters of Social and Humanistic Sciences 16(2) (2014) 132-143.

[70] Jason L. Powell, International Letters of Social and Humanistic Sciences 17(1) (2014) $1-60$.

[71] Mohsen Mehrara, Hamid Abrishami, Mostafa Boroujli, Mahan Amin, International Letters of Social and Humanistic Sciences 11 (2013) 76-83.

[72] Bahram Meihami, Hussein Meihami, International Letters of Social and Humanistic Sciences 3 (2014) 80-91.

[73] Rajesh K. Yadav, Nishant Dabhade, International Letters of Social and Humanistic Sciences 4 (2013) 49-69.

[74] Tomáš Hes, Alena Neradová, Karel Srnec, International Letters of Social and Humanistic Sciences 7 (2013) 55-75. 